\title{
DESCRIPTION OF A NEW TREE KANGAROO.
}

By Professor F. Foerster and the hon. Walter rothschild, Рh.D. (Plate IV.)

\section{Dendrolagus matschiei sp. nov.}

Hair more silky than in the other species, directed forward from a whorl in the centre of the back. Head, back, base of tail, ontside of forelegs, basal third of hindlegs, throat and chest of a bright golden rufous brown, narrow central line and flanks darker. Lower half of face and muzzle silver-grey. Tips of ears, feet, inner surface of legs, abdomen, and presumably rest of underside bright golden yellow. Tail brownish golden yellow.

Total length of skin $1404 \mathrm{~mm}$. Head and body $806 \mathrm{~mm}$. ; tail $598 \mathrm{~mm}$.

Habitat. Rawlinson Mountains, German New Guinea.

\section{ON A NEW RACE OF ORYCTEROPUS.}

By THE HON. WALTER ROTHSCHILD, Pн.D.

Orycteropus afer albicaudus subsp. nov.

Hitherto we have only been acquainted with five living races of Orycteropus. These races are as follows:

Orycteropus afer afer: Cape Colony, Natal.

O. afer wertheri: Hinterland of Bagamoyo, E. Africa (Matschie, in Werther's Mittl. Hochl. D.O. A frika p. 266 [1895]).

$O$. afer aethiopicus: Abyssinia and the Eastern Soudan.

O. afer senegalensis: Senegambia.

O. afer haussanus: Togo Hinterland.

I have lately received a very old individual from German South-West Africa which is conspicuously different from the forms mentioned above. Outwardly it is conspicnons by the uniform deep brown colour of the body, and very short tail, which is pnre white. The head is rosy greyish brown. It differs also markedly in its dentition, for it has in the lower and upper jaws only five teeth, while all the others, in the lower jaw at least, have six on each side. The teeth are nearest to those of $O$. afer senegalensis, and the last molar is almost identical, but the praemolar is large and pointed, while in the others the two praemolars are small and flat. For this new form I propose the name O. afer albicaudus.

Total length of skin $1649 \mathrm{~mm}$; head and body $1319 \mathrm{~mm}$; tail $330 \mathrm{~mm}$; skull from basion to end of gnathion $234 \mathrm{~mm}$.; palate $143 \mathrm{~mm}$.; length of last lower molar $10 \mathrm{~mm}$., of last but one $13 \mathrm{~mm}$.

Habitat: German South-West Africa. 


\section{$2 \mathrm{BHL}$ Biodiversity Heritage Library}

Foerster, F and Rothschild, Lionel Walter Rothschild. 1907. "Description of a new tree kangaroo." Novitates zoologicae : a journal of zoology in connection with the Tring Museum 14, 506-506. https://doi.org/10.5962/bhl.part.25383.

View This Item Online: https://www.biodiversitylibrary.org/item/21973

DOI: https://doi.org/10.5962/bhl.part.25383

Permalink: https://www.biodiversitylibrary.org/partpdf/25383

\section{Holding Institution}

Natural History Museum Library, London

\section{Sponsored by}

Natural History Museum Library, London

\section{Copyright \& Reuse}

Copyright Status: Public domain. The BHL considers that this work is no longer under copyright protection.

This document was created from content at the Biodiversity Heritage Library, the world's largest open access digital library for biodiversity literature and archives. Visit BHL at https://www.biodiversitylibrary.org. 